\title{
Native Gold from the Plavica Epithermal Deposit, Republic of Macedonia
}

\author{
V. Stefanova ${ }^{a}$, A. V. Volkov ${ }^{b}$, T. Serafimovskii ${ }^{a}$, \\ and Corresponding Member of the RAS A. A. Sidorov ${ }^{b}$ \\ Received February 27, 2013
}

\begin{abstract}
Mineralogical-geochemical studies have shown that gold from the Plavica high sulfidation epithermal deposit (Republic of Macedonia) contains an admixture of $\mathrm{Fe}$ and $\mathrm{Cu}$, that the morphology of gold indicates the proximity of the primary source, and that the chemical composition of gold is independent of its morphology. The composition of gold and its morphology are the direct searching criteria, indicating the genetic type of mineralization. Pan sampling and the subsequent study of the typomorphism of gold may serve as an effective method for searching for epithermal high sulfidation deposits. Pan sampling allows us to distinguish and study in detail the chemical composition and morphology of native gold from deposits of this type.
\end{abstract}

DOI: $10.1134 / \mathrm{S} 1028334 \mathrm{X} 1308014 \mathrm{X}$

Based on study of the geological structure, ore mineralogy, wall-rock alteration, and fluid inclusions, the Plavica deposit is referred to high sulfidation epithermal deposits [1]. Mineralogical study of gold in the stringer-disseminated ores of such deposits, as well as porphyry copper deposits, is rather difficult because of its small (often micrometric) sizes and low (first gpt) contents. This paper presents the results of study of native gold from the Plavica deposit based on an original method.

The Plavica deposit is located in the Kratovo region, $60 \mathrm{~km}$ east of the town of Skopje (Fig. 1, inset map). Historically, the exploration of gold and copper in this Balkan region began as early as the time of Alexander the Great and continued during the Roman and Ottoman empires. In recent years, the Australian company Genesis Resources LTD estimated the resources of the Plavica deposit as 58, 877, and $33900 \mathrm{t} \mathrm{Au}, \mathrm{Ag}$, and $\mathrm{Cu}$, respectively, at average content of $1 \mathrm{gpt} \mathrm{Au}, 25 \mathrm{gpt} \mathrm{Ag}$, and $0.43 \% \mathrm{Cu}$.

The Kratovo-Zletovo ore region is spatially combined with a volcanic area of the same name $\left(1200 \mathrm{~km}^{2}\right)$ at the boundary between the Serbian-Macedonian and Vardar ophiolite terrains [2] and is distinct due to the zonal occurrence of different polymetallic and precious metal mineralization [3]. The volcanic area is composed of the products of calc-alkaline magmatism with dominant Oligocene-Miocene andesites, dacites, and tuffs intruded by Pliocene basaltic dikes.

\footnotetext{
${ }^{a}$ Goce Del'cev University, Stip, Republic of Macedonia (FYROM)

${ }^{b}$ Institute of Geology of Ore Deposits, Petrography, Mineralogy, and Geochemistry, Russian Academy of Sciences, Staromonetnyi per. 35, Moscow, 119017 Russia
}

The central part of the area is made up of several volcanic structures, hosting the large volumes of the products of advanced argillic alteration (Fig. 1). Significant $\mathrm{Au}-\mathrm{Ag}-\mathrm{Cu}$ mineralization is related to the quartz-alunite rocks. The widest fields of hydrothermally altered rocks were found in the central parts of the Plavica deposit and CRN VRV $\left(0.2\right.$ and $0.4 \mathrm{~km}^{2}$ of rocks affected by argillic alteration and 8.0 and $10.0 \mathrm{~km}^{2}$ of altered rocks, respectively) near the town of Kratovo. Drilling has shown that the carrotlike bodies of quartz-alunite rocks are pinched out at a depth of $400 \mathrm{~m}$. They usually contain $97-98 \% \mathrm{SiO}_{2}$ and consists of amorphous and microcrystalline siliceous mass and opal. Tourmaline, pyrophyllite, diaspore, and adularia occur locally.

The Plavica deposit is controlled by a large Neogene volcanic center, complicating the structure of the paleocaldera $6.5 \mathrm{~km}^{2}$ in area. The main peculiarity of this structure is the great number of radial faults directed out of the central part (Fig. 1). The Zletovo polymetallic deposit is confined to the southern closing of the caldera. The host rocks of the deposit are ignimbrites, lavas, and tuffs of amphibole and amphibole-biotite andesites. The age of the majority of the igneous rocks of the deposit is $26.5 \pm 2 \mathrm{Ma}$ [4].

The total thickness of the volcanic rocks is about $1000 \mathrm{~m}$. A series of zones of monoquartz, silica, alunite, sericite, argyllic, and propilite hydrothermal alteration of the host rocks is distinguished outward from the deposit. Toward the center of the system, the areal alteration transits into fissure alteration with development of narrow linear zones hosting the polymetallic veins. Disseminated and stringer-disseminated ores are established in zones of quartz, sericite, and alunite alteration. The ore minerals are pyrite, chalcopyrite, enargite, tetrahedrite, molibdenite, gold 


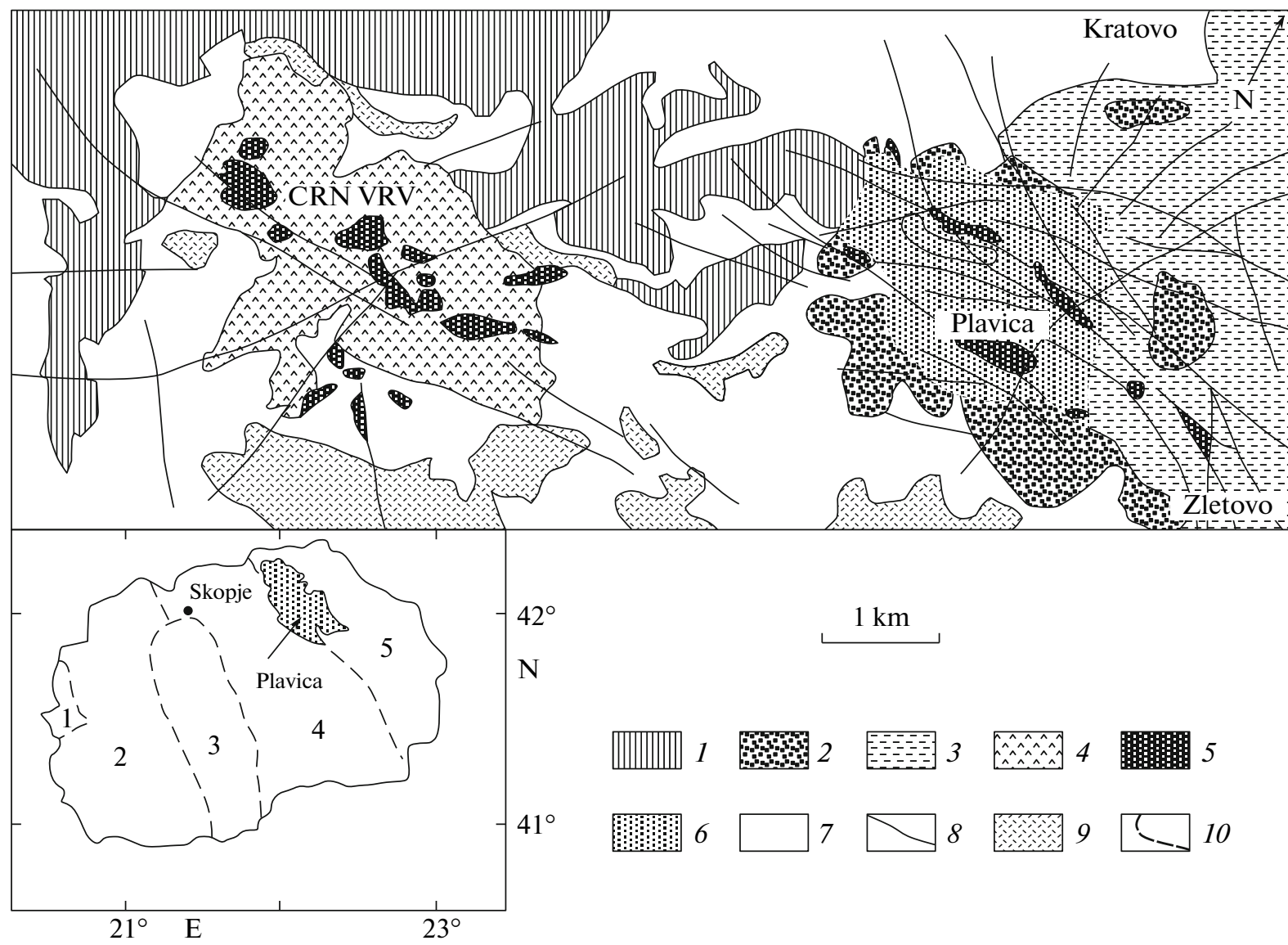

Fig. 1. Geological map of the Plavica ore field-CRN VRV, modified after [1]. The inset map shows the location of the Plavica deposit and the Kratovo-Zletovo volcanic field on the territory of Macedonia; numbers of zones correspond to the geological terrains, after [2]. (1) Pyroxene-biotite andesite; (2) quartz andesite; (3) ignimbrite; (4) andesite tuff; (5) bodies of quartzalunite rocks; (6) intensely hydrothermal alteration; (7) Oligocene-Pliocene sedimentary rocks; (8) area of development of the $\mathrm{Cu}$ - and $\mathrm{Au}$-rich quartz-enargite veins (Zlatica); (9) pyroxene andesite; (10) faults.

and its tellurides, bornite, chalcocite, covellite, sphalerite, galena, pyrrhotite, magnetite, hematite, and rutile (Fig. 2). The vertical size of the orebody exceeds $300 \mathrm{~m}$ and is not contoured to the depths. The possible vertical size of mineralization is more than $1000 \mathrm{~m}$, judging from a structural well $900 \mathrm{~m}$ deep, which stopped in the ore.

The study of gold involved field and laboratory works. The field works included pan sampling of the endogene mineralization from the streams, which drain the ore field with an area of $70 \mathrm{~km}^{2}$, following the standard method. Gold was found in 15 pan samples. Thus, 44 grains were selected for further investigations. The pan samples were mostly composed of pyrite and magnetite, occasional chalcopyrite, widespread feldspars and quartz, and rare muscovite, gypsum, and zircon. The morphology and composition of gold were studied on a JMS 5510 JEOL SEM at the University of Sofia, Bulgaria, a TRACTOR NORTHERN TN-2000 microprobe, and a JEOL LMS 35 CF SEM, using the standards of the JEOL Company. In addition, micro- probe analyses were carried out on a Philips SEM 505 SEM equipped with an EDAX 91000/60 at the Laboratory for Photoprocesses of the Bulgarian Academy of Sciences, Sofia.

Based on SEM study, the pan gold from the Plavica deposit is $50-200 \mu \mathrm{m}$ in size. Three morphological groups of grains were distinguished: isometric-elongated, irregular, and dendrite-laminar (Fig. 3). It should be noted that very small grains typically are irregular or isometric and some grains have a complicate morphology (Fig. 3). By the classification of N.V. Petrovskaya [5], gold from the Plavica deposit belongs to the group of the very small grains. Almost all grains of gold are characterized by a layered structure (Figs. 3a-3d); crystals, dendrites, and shell-like gold grains (Figs. 3a, 3b) were also observed (Fig. 3). The secondary minerals intruded into the gold grains probably during the alluvial transportation (Fig. 3f).

The chemical composition of gold based on microprobe analyses is shown in the table. The native gold from the Plavica deposit has a high fineness (842- 

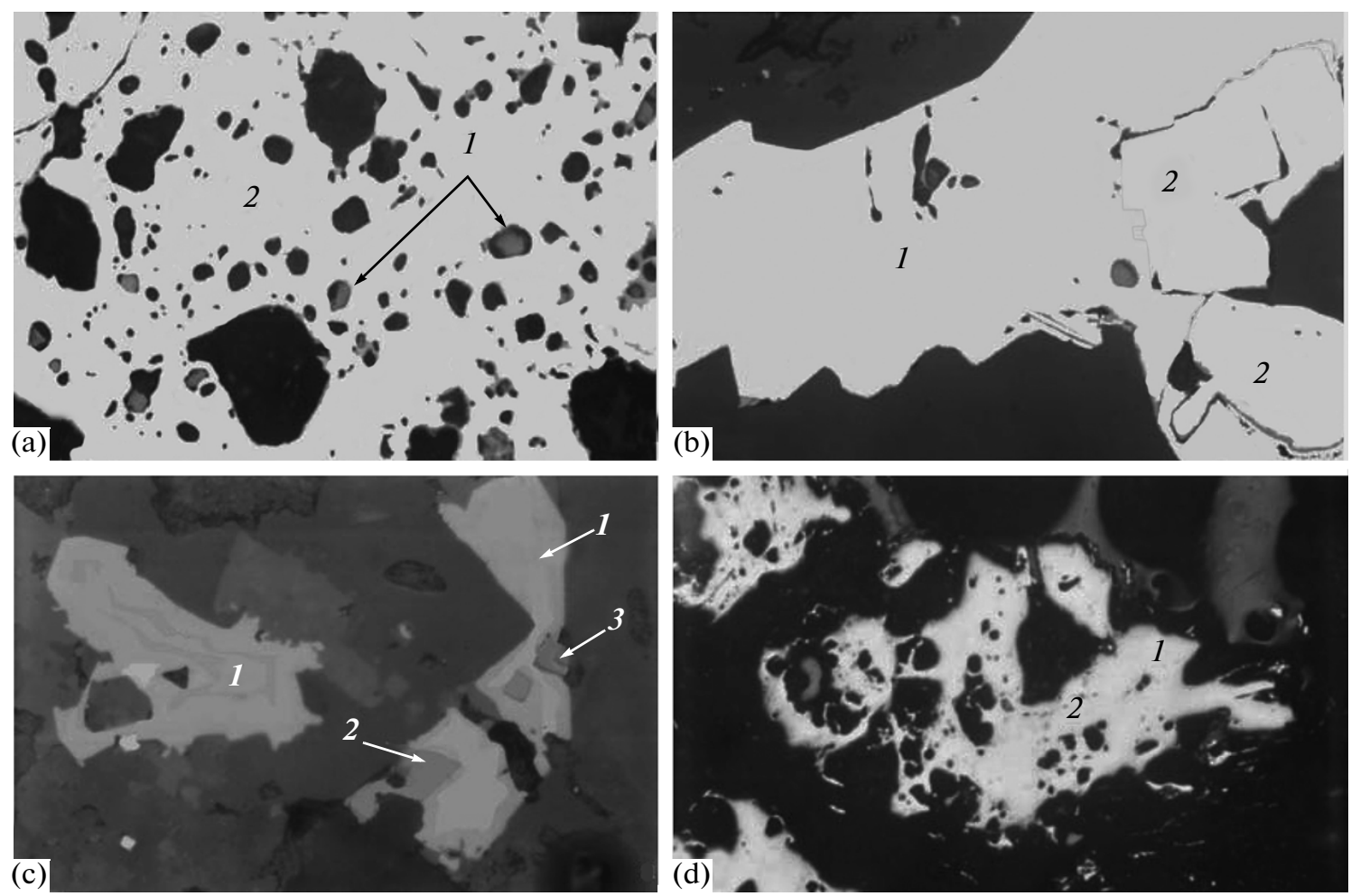

Fig. 2. Morphological peculiarities of the major ore minerals from the Plavica deposit (reflected light). (a) "Bird's eye" structure: pyrrhotite (1) in pyrite (2), magnification of 63; (b) subhedral chalcopyrite (1) with euhedral pyrite (2), magnification of 63; (c) aggregates of tennantite (1) with sphalerite (2) and magnetite (3), magnification of 126; (d) tennantite grain (1) with inclusions of sphalerite (2), magnification of 63 .

994\%o) (table, Fig. 4). The Ag content in the gold varies from $0.18 \mathrm{wt} \%$ (PL-11/1, three grains) up to $21.07 \mathrm{wt} \%$ (PL-5). It should be noted that one gold grain had very high fineness (990-994\%o). Rather high Ag contents were identified in two grains: 19.4321.07 wt \% (PL-5) and 10.56-14.42 wt \% (PL-12). However, the chemical composition of gold in ores from the Plavica deposit is stable and homogeneous. In addition to $\mathrm{Ag}$, the gold contains an admixture of $\mathrm{Cu}(0.25-0.68 \mathrm{wt} \%)$ and, locally, an insignificant amount of Fe (0.08-0.28 wt \%). As is shown in the table, the composition of gold grains is relatively stable and homogeneous and $\mathrm{Ag}$ is evenly distributed in the gold grains, having almost the same contents both in the center and at the periphery. However, as is seen from the table, the central parts of the grains from the PL-3 and PL-14 samples are depleted in Ag in contrast to the marginal parts with higher Ag contents. The opposite picture is observed in the gold grain from the PL-11 sample: it is enriched in Ag in the center relative to the periphery. Such differentiation of the gold fineness is probably related to its purification during transportation [6].

The table shows that the average $\mathrm{Au}$ contents in individual grains vary from 79.01 to $99.24 \mathrm{wt} \%$. The average Au content for the Plavica deposit is generally $92.03 \mathrm{wt} \%$. The histogram demonstrates the variation of the Ag contents in gold from the Plavica deposit (Fig. 4). It is evident that most analyses are characterized by low $\mathrm{Ag}$ contents and the distribution curve is lognormal and slightly inclined toward the higher contents. The average $\mathrm{Ag}, \mathrm{Cu}$, and $\mathrm{Fe}$ contents in gold from the Plavica deposit are $7.22,0.44$, and 0.075 wt $\%$, respectively. The average $\mathrm{Cu}$ and $\mathrm{Fe}$ contents vary from 0.34 to $0.56 \mathrm{wt} \%$ and from 0.05 to $0.10 \mathrm{wt} \%$, respectively.

The results of the study are similar to the previously published data on porphyry copper deposits from the Buchim-Damjan-Borov Dol ore region [7]. It should be noted that gold from the Plavica deposit is distinct from gold of these deposits, on average, by the high fineness and higher $\mathrm{Fe}$ and lower $\mathrm{Cu}$ contents. No electrum was identified among the pan gold from the Plavica deposit.

Thus, mineralogical-geochemical studies have shown that gold from the Plavica high sulfidation epithermal deposit is similar to that from the porphyry copper deposits of the Buchim-Damjan-Borov Dol ore region of the Republic of Macedonia. The gold from the Plavica deposit is chemically homogeneous, is characterized by high fineness, and contains notable $\mathrm{Fe}$ and $\mathrm{Cu}$ contents. The chemical composition of gold is independent of its morphology, which indicates 

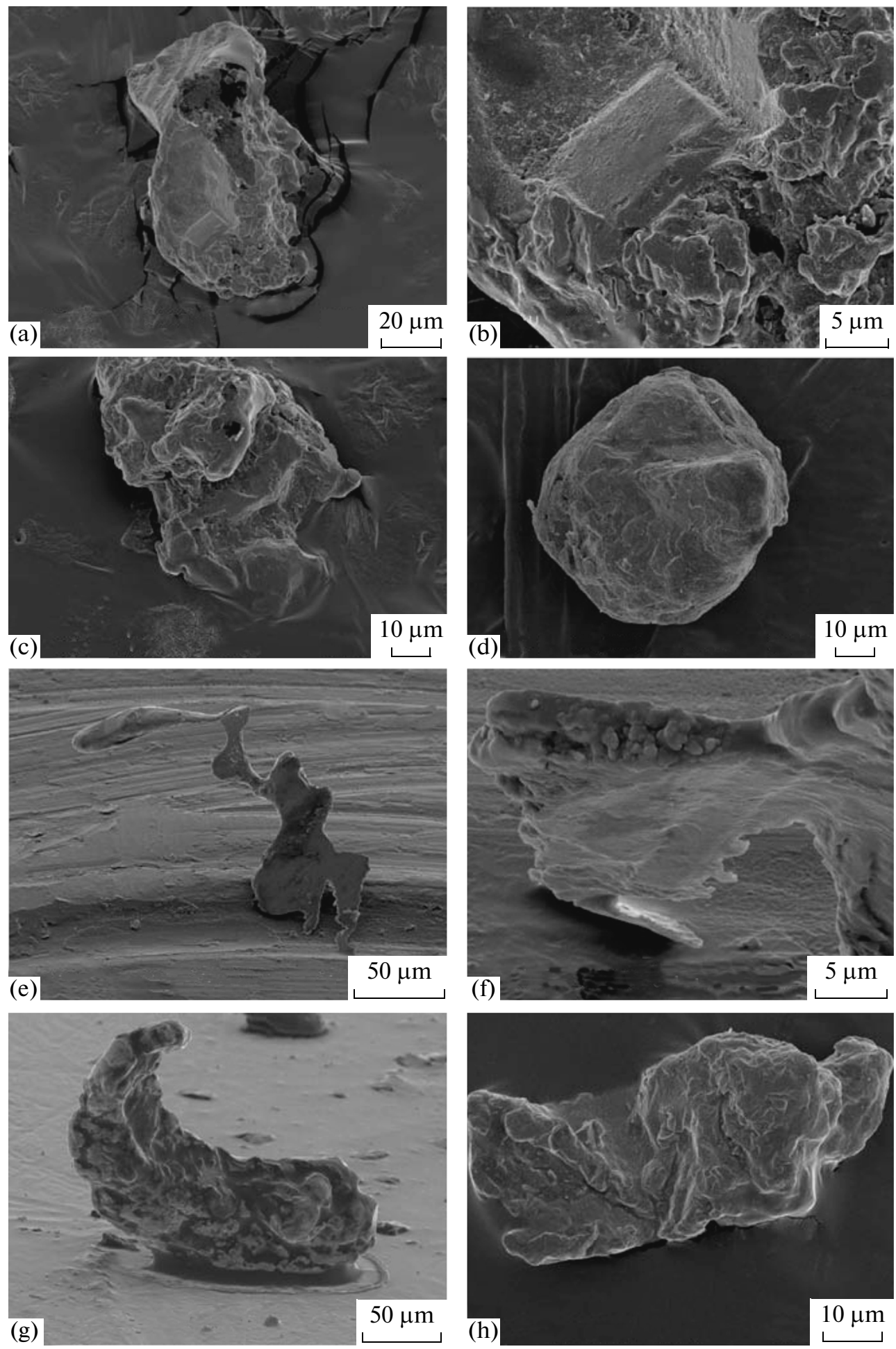

Fig. 3. Morphology of gold grains and their fragments from the Plavica deposit. (a) Elongated-isometric gold grain; (b) crystalline and layered structure of gold (a detail of the previous image); (c) irregular gold grain; (d) spherical gold grain; (e) dendrite of gold; (f) a detail of the previous grain; (g) shell-like gold grain; (h) elongated gold grain with evident layered structure.

the proximity of the primary source. Thus, the gold composition and its morphology are the direct searching criteria, indicating the development of high sulfi- dation epithermal deposits. Pan sampling and study of the typomorphism of gold may serve as an effective method for the search for high sulfidation epithermal 
Microprobe analyses of gold from the Plavica deposit, wt \%

\begin{tabular}{|c|c|c|c|c|c|c|}
\hline \multirow{2}{*}{$\begin{array}{c}\text { Number of sam- } \\
\text { ple/grain }\end{array}$} & \multirow{2}{*}{ Point of analysis } & \multicolumn{5}{|c|}{ Elements } \\
\hline & & $\mathrm{Au}$ & $\mathrm{Ag}$ & $\mathrm{Cu}$ & $\mathrm{Fe}$ & $\mathrm{S}$ \\
\hline \multirow[t]{4}{*}{ PL-1 } & 1 center & 95.68 & 2.94 & 0.57 & - & 99.19 \\
\hline & 2 periphery & 95.98 & 2.76 & 0.49 & - & 99.23 \\
\hline & 3 periphery & 96.59 & 3.13 & 0.29 & 0.22 & 100.23 \\
\hline & Average & 96.08 & 2.94 & 0.45 & 0.07 & \\
\hline \multirow[t]{4}{*}{ PL-3/1 } & 1 center & 94.01 & 4.95 & 0.29 & - & 99.25 \\
\hline & 2 periphery & 94.21 & 5.58 & 0.51 & - & 100.30 \\
\hline & 3 periphery & 94.20 & 5.33 & 0.21 & 0.16 & 99.90 \\
\hline & Average & 94.14 & 5.29 & 0.34 & 0.05 & \\
\hline \multirow[t]{4}{*}{ PL-3/2 } & 1 center & 97.91 & 2.13 & 0.27 & 0.11 & 100.42 \\
\hline & 2 periphery & 95.82 & 3.51 & 0.50 & - & 99.83 \\
\hline & 3 periphery & 92.78 & 6.02 & 0.64 & - & 99.44 \\
\hline & Average & 95.50 & 3.89 & 0.47 & 0.04 & \\
\hline \multirow[t]{4}{*}{ PL-3/3 } & 1 center & 94.39 & 4.58 & 0.57 & - & 99.54 \\
\hline & 2 periphery & 88.57 & 10.58 & 0.31 & 0.20 & 99.66 \\
\hline & 3 periphery & 92.23 & 7.05 & 0.68 & - & 99.96 \\
\hline & Average & 91.73 & 7.40 & 0.52 & 0.07 & \\
\hline \multirow[t]{3}{*}{ PL-4 } & 1 center & 92.91 & 6.6 & 0.27 & 0.19 & 99.97 \\
\hline & 2 periphery & 94.21 & 5.02 & 0.57 & - & 99.80 \\
\hline & Average & 93.56 & 5.81 & 0.42 & 0.10 & \\
\hline \multirow[t]{4}{*}{ PL-5 } & 1 center & 80.17 & 19.43 & 0.37 & - & 99.97 \\
\hline & 2 periphery & 78.69 & 21.07 & 0.44 & 0.14 & 100.34 \\
\hline & 3 periphery & 78.18 & 20.93 & 0.41 & 0.20 & 99.72 \\
\hline & Average & 79.01 & 20.48 & 0.41 & 0.11 & \\
\hline \multirow[t]{4}{*}{ PL-11/1 } & 1 center & 96.33 & 2.91 & 0.43 & - & 99.67 \\
\hline & 2 periphery & 93.69 & 5.9 & 0.44 & - & 100.03 \\
\hline & 3 periphery & 93.66 & 5.55 & 0.35 & 0.22 & 99.78 \\
\hline & Average & 94.56 & 4.79 & 0.41 & 0.07 & \\
\hline \multirow[t]{5}{*}{ PL-11/2 } & 1 center & 99.60 & - & 0.44 & - & 100.04 \\
\hline & 2 periphery & 98.86 & - & 0.41 & 0.09 & 99.36 \\
\hline & 3 periphery & 98.77 & 0.27 & 0.43 & - & 99.47 \\
\hline & 4 periphery & 98.40 & 0.46 & 0.34 & - & 99.20 \\
\hline & Average & 98.90 & 0.18 & 0.41 & 0.02 & \\
\hline \multirow[t]{4}{*}{ PL-11/3 } & 1 center & 99.09 & 0.52 & 0.63 & 0.19 & 100.43 \\
\hline & 2 periphery & 99.44 & 0.31 & 0.46 & 0.18 & 100.39 \\
\hline & 3 periphery & 99.18 & 0.18 & 0.44 & - & 99.80 \\
\hline & Average & 99.24 & 0.34 & 0.51 & 0.12 & \\
\hline \multirow[t]{4}{*}{ PL-12 } & 1 center & 85.81 & 13.25 & 0.39 & 0.09 & 99.54 \\
\hline & 2 periphery & 89.49 & 10.56 & 0.35 & 0.17 & 100.57 \\
\hline & 3 periphery & 84.24 & 14.42 & 0.47 & 0.11 & 99.24 \\
\hline & Average & 86.51 & 12.74 & 0.40 & 0.12 & \\
\hline \multirow[t]{4}{*}{ PL-13/1 } & 1 center & 97.15 & 2.25 & 0.25 & - & 99.65 \\
\hline & 2 periphery & 97.71 & 1.41 & 0.38 & 0.28 & 99.78 \\
\hline & 3 periphery & 97.09 & 1.56 & 0.43 & - & 99.08 \\
\hline & Average & 97.32 & 1.74 & 0.35 & 0.09 & \\
\hline \multirow[t]{4}{*}{ PL-13/2 } & 1 center & 93.89 & 5.58 & 0.47 & - & 99.94 \\
\hline & 2 periphery & 94.55 & 4.09 & 0.57 & 0.08 & 99.29 \\
\hline & 3 periphery & 91.71 & 7.81 & 0.45 & 0.08 & 100.05 \\
\hline & Average & 93.38 & 5.83 & 0.50 & 0.05 & \\
\hline \multirow[t]{4}{*}{ PL-14 } & 1 center & 96.12 & 2.98 & 0.50 & - & 99.60 \\
\hline & 2 periphery & 94.06 & 5.13 & 0.63 & - & 99.82 \\
\hline & 3 periphery & 92.96 & 6.16 & 0.54 & - & 99.66 \\
\hline & Average & 94.38 & 4.76 & 0.56 & 0 & \\
\hline Plavica & Average & 92.03 & 7.22 & 0.44 & 0.075 & \\
\hline
\end{tabular}


Amount of measurements

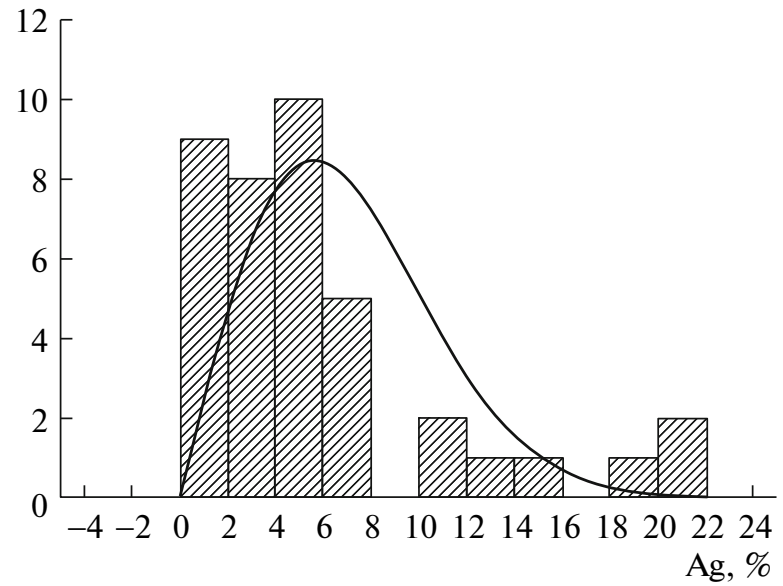

Fig. 4. Histogram of Ag distribution in the pan gold from the Plavica deposit $(n=39)$.

deposits. In addition, pan sampling allows us to distinguish and study in detail the chemical composition and morphological peculiarities of native gold of the deposits of this type.

\section{ACKNOWLEDGMENTS}

This work was supported by the Russian Foundation for Basic Research (project no. 11-05-00006-a) and the Department of Earth Sciences of the Russian Academy of Sciences (program no. 2).

\section{REFERENCES}

1. D. H. M. Alderton and T. Serafimovskii, Appl. Earth Sci. 116 (2), 94-105 (2007).

2. N. Dumurdzanov, T. Serafimovski, and B. C. Burchfiel, Geosphere, No. 1, 1-22 (2005).

3. V. Cifliganec, S. Jankovic, and T. Serafimoski, Rom. J. Miner. Dep. 78 (2), 85-92 (1997).

4. T. Serafimovskii, Structural-metallogenetic features of the Lece-Halkidiki zone: Types of the mineral deposits and distribution (Geol. depart., Faculty of Mining and Geology, Stip, 1993).

5. N. V. Petrovskaya, Native gold (Nedra, Moscow, 1973) [in Russian].

6. R. J. Champan, R. C. Leake, N. R. Moles, et al., Econ. Geol. 95, 1753 (2000).

7. A. V. Volkov, V. Stefanova, T. Serafimosvkii, and A. A. Sidorov, Dokl. Earth Sci. 422 (7), 1013-1017 (2008). 